Article

\title{
Making Administrative Systems Adaptive to Emerging Climate Change-Related Health Effects: Case of Estonia
}

\author{
Kati Orru ${ }^{1, *}$, Mari Tillmann ${ }^{2}$, Kristie L. Ebi ${ }^{3}$ and Hans Orru ${ }^{4,5}$ (iD \\ 1 Institute of Social Sciences, University of Tartu, Lossi 36, 51003 Tartu, Estonia \\ 2 Estonian Police and Border Guard Board, Pärnu mnt 139, 15060 Tallinn, Estonia; mari.tillmann@politsei.ee \\ 3 Department of Global Health, University of Washington, Seattle, WA 98105, USA; krisebi@uw.edu \\ 4 Institute of Family Medicine and Public Health, University of Tartu, Ravila 19, 50411 Tartu, Estonia; \\ hans.orru@ut.ee \\ 5 Department of Public Health and Clinical Medicine, Umea University, 90187 Umea, Sweden \\ * Correspondence: kati.orru@ut.ee; Tel.: +372-737-5188
}

Received: 30 April 2018; Accepted: 5 June 2018; Published: 9 June 2018

\begin{abstract}
To facilitate resilience to a changing climate, it is necessary to go beyond quantitative studies and take an in-depth look at the functioning of health systems and the variety of drivers shaping its effectiveness. We clarify the factors determining the effectiveness of the Estonian health system in assessing and managing the health risks of climate change. Document analyses, expert interviews with key informants from health systems whose responsibilities are relevant to climate change, and analysis of a population-based survey conducted in 2015 , indicate that the health effects of climate change have not been mainstreamed into policy. Therefore, many of the potential synergistic effects of combining information on health systems, environment, and vulnerable populations remain unexploited. The limited uptake of the issue of climate change-related health risks may be attributed to the lack of experience with managing extreme weather events; limited understanding of how to incorporate projections of longer-term health risks into policies and plans; unclear divisions of responsibility; and market liberal state approaches. Minority groups and urban dwellers are placing strong pressure on the health system to address climate change-related risks, likely due to their lower levels of perceived control over their physical wellbeing. The results have implications for national, community, and individual resilience in upper-middle income countries in Eastern Europe.
\end{abstract}

Keywords: health systems; climate adaptation; health infrastructure; rescue services; Northern Europe

\section{Introduction}

It is expected that the health risks of climate change will increase globally, with increases in morbidity and mortality from selected climate-sensitive health outcomes, putting additional pressures on health systems [1,2]. The effectiveness of adaptation is influenced by a country's physical location and exposure to climate shocks, levels of socioeconomic development, and healthcare capacity to prepare for and manage climate-related shocks [3]. Tailoring effective adaptation measures requires a clear understanding of which factors led to today's preparedness to manage climate change. Researchers have been urged to pay more attention to the role of the nation state in climate governance, as these actors have the legitimacy and resources to develop long-term visions, stimulate and oversee local approaches, and carry forward adaptation programs, e.g., [4]. In their analysis of health adaptation initiatives in ten Organization for Economic Co-operation and Development (OECD) countries, Austin et al. concluded that national governments play a key role in health adaptation to climate change, but there are competing views on what responsibilities and obligations this will—or 
should-include [5]. One view suggests increasing investments in existing public health infrastructure to manage the projected health risks [6]. The second argues climate change will likely affect health by, for instance, destabilising supporting systems or threatening infrastructure, thus necessitating new and innovative responses. Suggested factors for successful adaptation include adopting legislation, ensuring interdepartmental coordination, and increasing self-governance [7-9]. We take an in-depth look at health and rescue systems in Estonia, because they will play a key role in climate adaptation policies in connection with the EU climate change strategy [10].

Informed by the research on risk governance [11,12], we analyse the health and rescue system as a control system for achieving policy goals; assess factors shaping those goals; and assess the factors shaping the process of information-gathering and implementation of protective measures, such as early warning systems or emergency preparations. We examine the extent to which outside (e.g., issue salience) and inside (e.g., institutional capacities and rules) drivers of the health systems shape the success of climate adaptation. We apply the World Health Organization's Operational Framework for Building Climate Resilient Health Systems [13] to understand how the quality of leadership and governance, health workforce, health information systems, medical technologies, service delivery, and climate and health financing shape the quality, efficiency, equity, accountability, and resilience of the health systems [14].

\subsection{Climate Change Adaptation of Health Systems}

We adopt a case-study framework of adaptation of health systems (Figure 1). For analytic purposes, the framework distinguishes between the processes of elaborating policy programmes, monitoring, and information-gathering, and enforcing protective measures. The framework recognises significant overlaps and feedback loops between these responsibilities of the Estonian health system. Effective and timely responses depend on effective policies, strategies, and action plans crafted by political leaders to manage climate-sensitive health outcomes. The WHO Operational Framework specifies that in order to continuously deliver health services throughout climate-related events, governments should modify emergency management plans and incorporate up-to-date risk assessments. In line with the European Union's climate change adaptation strategy [15], most European countries have developed national strategies, but few countries have implemented regulations and operational plans for authorities and healthcare systems to manage health-related issues.

Monitoring and gathering information of health and health system conditions provides information for timely responses and behaviour change, but also for setting new goals and amending legislation. The WHO Operational Framework [13] identifies three key areas that health information systems must develop: vulnerability, capacity, and adaptation assessments; risk monitoring; and climate and health research. Risk monitoring systems provide timely, detailed information on current and future environmental conditions that may affect health and the ability of health systems to provide services. In the context of climate change, hurdles for new interventions may arise in the form of evidence provision; climate will continue to change over coming decades, with uncertainties associated with the rate and magnitude [16,17]. The tendency of turning a "blind eye" towards policy problems by limiting investments in surveillance and monitoring may work to maintain the status quo in state investments [18].

As for timely responses and protective measures, monitoring systems coupled with communication networks (early warning systems) can be designed to alert members of the public when environmental hazards may affect their health. However, existing health safety programs excessively focus on providing information [19] without considering the need to change motivation and supportive infrastructure, living arrangements, and skills. For example, climate change can affect the ability of healthcare systems to provide services during extreme weather events because of infrastructure damage and medical supply disruptions [13]. 


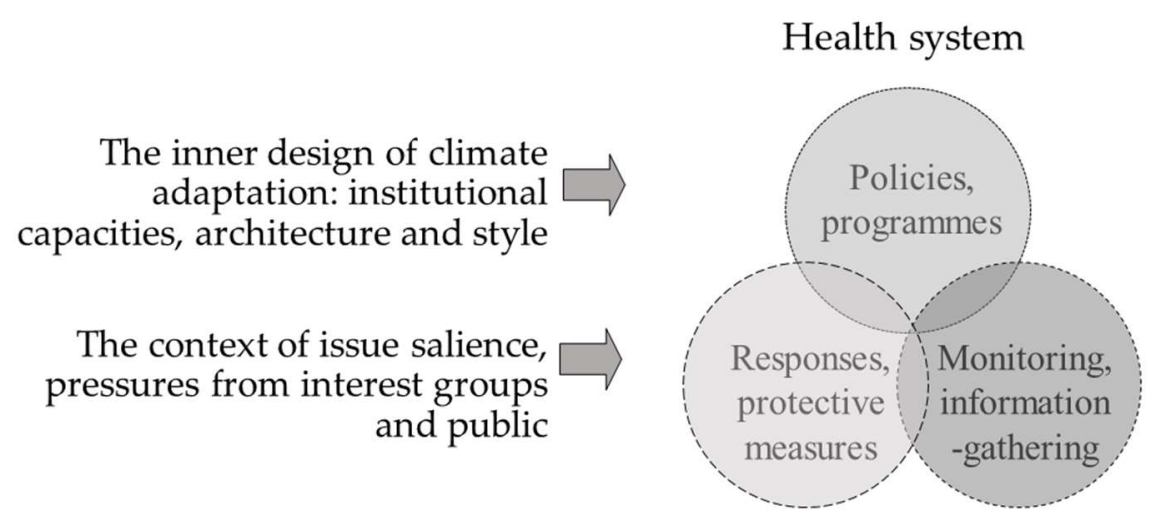

Figure 1. Determinants of climate adaptation of health systems.

\subsection{Factors Influencing Adaptation of Policy Programmes, Monitoring Systems, and Response Measures}

Effectively adapting to the health risks of climate change includes internal factors related to administering health systems, such as management structure and capability, and external factors, including the pressure of interest groups and the public. The internal functioning of health systems is often characterised by administrative cultures of reactivity and lack of long-term future orientation. The administrative focus is tightly related to the risk calculus that politicians make; this includes issues such as the visibility of the problem (which may be obvious to experts but far less so to the general public and politicians) and the avoidability of blame (for events that lead to damage) [20,21]. By contrast, the notion of institutional adaptive capacity [22] highlights the proactive provision of means and information to enable social actors to anticipate possible futures and take preventive measures.

Administrative capacity is the health system's economic aptitude, technical preparedness, and competence and sufficiency of human resources; these factors may influence the development and application of adaptation policy [23]. At lower level administrative units, larger municipalities are likely to have more human and financial resources to direct to adaptation [24,25]. Maintaining a healthy and effective practitioner workforce, products, and technologies are critical challenges for health systems [13]. Beyond human and financial resources, institutions should have the authority to generate political and legal incentives for actors to change [26].

The administrative architecture is crucial in the design of adaptation policy, as multilevel institutions and networks are needed for the process to be successful [27]. Developing effective adaptation plans requires coordination and collaboration between health ministries and other government agencies and non-governmental partners, to ensure that the actions undertaken foster positive health outcomes [13]. Policy coherence literatures (see Tosun and Lang, 2017 [28]) highlight the demanding task of integrating institutions, particularly in cases with an increasing number of affected interests, such as health [29] or security [30].

The most obvious contextual driver of political and administrative action is the effect of extreme events spurring increased awareness and policy innovation [18]. In general, climate change is difficult to understand and psychologically distant for lay people and political and administrative actors [31]. However, according to the policy-window hypothesis, following a disaster, the political climate may be conducive to legal, economic, and social change that can begin to reduce structural vulnerabilities [32].

Based on strong interests, non-governmental organisations, entrepreneurs, or the scientific community can influence health risk governance [12]. Robust climate and health research agendas should expand and improve the quality of knowledge [33]. However, the scarcity of scientific evidence of the emergence of climate change-related health impacts may challenge the ability to develop effective adaptation options [34]. 
In countries of the former Soviet Union, the role of non-governmental organisations in developing and applying regulatory regimes has been modest [18]. This may change as national groups advocating a certain policy or action gain prominence when an issue is placed on the political agenda and reaches a certain level of salience [35].

International organisations pose crucial pressures; the adoption of climate policies in the OECD countries was influenced by learning from international organisations [36]. The issue of climate change entered the political agendas of Central and Eastern European countries through the EU [37,38]. Exemplary neighbouring states are urging other EU countries to tighten their mitigation policies [36,39].

In the context of climate change, this study takes a comprehensive look at external pressures and factors characterising the internal working of the Estonian health system. We first present empirical data and methods that are used to validate our expectations. We then discuss background information about Estonia's health systems' adaptation to climate change. In subsequent sections, we discuss how the dominant ideas, administrative structures and capacities, and windows of opportunity have shaped the current situation with respect to adaptation politics.

\section{Methods}

Estonia lies in the North-Eastern corner of Europe. Out of a population of 1.3 million, $35.5 \%$ are nationalities other than Estonian, including Russians (25\%). One million people $(77.2 \%$ of the population) live in urban areas [40]. Income disparities are relatively large at 33.2\% [40]. The health inequalities among different age, education, and ethnicity groups are considerably larger in Estonia than in other Nordic countries [41]. For example, life expectancy among Estonians is 78.5 years, and non-Estonians 76.5, and total life expectancy is 77.6 years in Estonia, compared with 81.1 years in Finland [42].

For analysing the health systems' amenability to internal and contextual pressures, Estonian legislative acts, directives, strategic documents, such as activity plans, and their implementation were examined. In addition, 21 semi-structured interviews were conducted with key experts connected to health system adaptation in Estonia, ranging from policy designers to officials to scientists to social workers (Appendix A). The interviews clarified the expert's observations and experiences with the functioning of the Estonian health system and the actors and processes shaping its effectiveness. The interviews addressed the questions of the capability of the health and rescue system, operability of implemented measures, and the importance of various factors in shaping health system adaptation (Appendix B). The interviews were conducted in the spring of 2015 when compiling an adaptation strategy for the reducing the health risks of climate change and when health impact assessments were in their infancy [43].

To address public salience as an external driver of adaptation governance, we use a survey on environmental health risk perception and coping conducted in Estonia in 2015 of persons aged 18-75 years, stratified by age, sex, and geographical location [44]. The survey invited 2207 participants (administered by IBP Saar Poll), of which 1000 agreed (45.3\% response rate). We used a semi-structured questionnaire constructed to assess climate change-related issues, such as perceived exposure to extreme weather events, demand for state support for coping with extreme events, beliefs about state institutions' efficacy in taking care of the healthfulness of the environment, and concerns about health risks from the environment (Appendix C). Additionally, the instrument had entries for respondents' demographic data and self-rated health status.

We used a logistic regression analysis to estimate which factors were associated with perceived needs for measures for coping with the health risks of climate change. For statistical modelling of covariates of perceived need, we collapsed perceived need ratings into dichotomous groups by combining the answers high to total agreement (scores 4-5) into a group perceiving need, and the other categories as not. We recoded worry about health risk to self and family arising from the environment, as scores 1 and 2 = group 1 , score $3=$ group 2 , and scores 4 and $5=$ group 3. 


\section{Results}

Despite the relatively milder impacts of climate change on Northern and Eastern Europe under the more pessimistic RCP8.5 emission pathway, up to 1000 additional premature deaths due to heatwaves are projected annually by the end of the 21st century [45]. In northern Europe, the number of heatwave days are projected to increase by 2.4 times during the warmest months [33]. Also, the likelihood of forest fires could increase, and pollen seasons will be prolonged, with an increase in the number of new allergens [46,47]. Climate change could affect the spread of leishmaniosis, hantavirus, tick-borne encephalitis, dengue fever, and tularaemia in the region [48]. Among other European areas, the northern European region is projected to experience significant increases in future strong storms (intensity of high-impact wind speed and extreme cyclone frequency) [49]. An increase in the frequency of extreme weather, storms, and torrential rain may bring increased risks of physical danger. Climate change-related increases in the number of glazed frost days and prolonged periods of heatwaves threaten the elderly and chronically ill. These projected risks pose a direct challenge not only to medical care and rescue capacity, but also to social security services and informal support networks.

\subsection{Adapting Health Systems to Climate Change}

\subsubsection{Planning Responses to Climate Change-Related Health Risks}

Managing climate change-related health risks are divided between several ministries and their subdivisions in Estonia (Table 1). The Ministry of Social Affairs coordinates environmental health politics following the National Health Plan 2009-2020 [50], without explicitly considering the health risks associated with climate change. The Ministry of Environment Environmental Strategy 2030 and National Environmental Action Plan recognise the need to increase understanding of health risks, including through increasing awareness about health risks in environment and educational specialists and in the population, and in those responsible for managing emergency situations [51,52].

Table 1. Key institutions and responsibilities in policymaking, monitoring, and protective measures in relation to climate change adaptation.

\begin{tabular}{|c|c|c|c|c|}
\hline Key Institutions & $\begin{array}{l}\text { Policies and } \\
\text { Programmes }\end{array}$ & $\begin{array}{c}\text { Monitoring and } \\
\text { Information-Gathering }\end{array}$ & $\begin{array}{c}\text { Responses and Protective } \\
\text { Measures }\end{array}$ & $\begin{array}{c}\text { Addressing } \\
\text { Climate Change? }\end{array}$ \\
\hline $\begin{array}{l}\text { Ministry of Social } \\
\text { Affairs, Health } \\
\text { Board, National } \\
\text { Institute for Health } \\
\text { Development }\end{array}$ & $\begin{array}{l}\text { National Health } \\
\text { Plan } 2020\end{array}$ & $\begin{array}{l}\text { Health Board: monitoring and } \\
\text { prevention of infectious } \\
\text { diseases, vector transmitted } \\
\text { diseases, including cyanotoxins } \\
\text { in bathing water }\end{array}$ & $\begin{array}{l}\text { Health Board: Information on } \\
\text { web on prevention of } \\
\text { infectious diseases, vector } \\
\text { transmitted diseases. }\end{array}$ & No \\
\hline $\begin{array}{l}\text { Ministry of } \\
\text { Environment, } \\
\text { Weather Service }\end{array}$ & $\begin{array}{l}\text { Environmental } \\
\text { Strategy } 2030\end{array}$ & $\begin{array}{l}\text { Weather Service [53-55]: } \\
\text { European forecast model } \\
\text { HIRLAM, Weather Alert System } \\
\text { Meteoalarm, Baltic Sea forecast } \\
\text { models HIROMB; UV radiation; } \\
\text { pollen content for allergens }\end{array}$ & $\begin{array}{l}\text { Weather Service: forecasts and } \\
\text { warnings on web: Estonian } \\
\text { Weather Service, Air Quality } \\
\text { Management System [56]. }\end{array}$ & $\begin{array}{l}\text { Included in } \\
\text { environment } \\
\text { monitoring }\end{array}$ \\
\hline Ministry of Interior & $\begin{array}{l}\text { Emergency Act } \\
\text { [57], Internal } \\
\text { Security } \\
\text { Development Plan } \\
\text { 2015-2020 }\end{array}$ & $\begin{array}{l}\text { Rescue Board in collaboration } \\
\text { with Health Board conducts risk } \\
\text { analysis for emergency } \\
\text { situations including floods, } \\
\text { extensive forest fires, extremely } \\
\text { cold and warm weather }\end{array}$ & $\begin{array}{l}\text { Emergency plans for } \\
\text { large-scale forest or landscape } \\
\text { fires; storms and floods in } \\
\text { densely populated areas; } \\
\text { epidemics. Instructions on } \\
\text { behaviour during emergencies } \\
\text { on Crisis web }\end{array}$ & $\begin{array}{l}\text { Included in } \\
\text { rescue capacity }\end{array}$ \\
\hline
\end{tabular}

Emergency situations that potentially affect health, including extremely hot or cold weather, storms, large-scale landscape or forest fires, floods in densely populated areas, and epidemics, are regulated by the Emergency Act [57]. According to the Internal Security Development Plan 2015-2020 [58], the goal is to ensure preparedness for disasters resulting from extreme weather conditions caused by climate change, and to develop procedures for disaster management. 
Baseline research for a more comprehensive Climate Strategy was initiated in 2015 to follow the EU Climate Adaptation Directive [15]. Interviews found there was not a perceived need to deal with adaptation separately. The respondents found that healthcare, environmental health, and rescue services are sufficiently regulated by legislative acts and strategic documents. An official of the Ministry of the Interior (29 April 2015): "Everything is in its place legislatively, and if anything needed to be changed it is rather the organisation of work."

\subsubsection{Gathering Information and Monitoring the Situation}

Different organisations monitor and forecast weather conditions. The Estonian Weather Service uses several European forecasting models and alert systems (Table 1) [53-55] and measures UV radiation. Measuring the quality of drinking and bathing water, spread of infectious diseases, and vector-transmitted diseases is the responsibility of the Health Board [59]. Not addressed are the spread of potentially infectious agents, vectors, airborne mould, and changes in indoor environments associated with climate change.

The Environmental Health Research Centre under the Estonian Health Board was active during the period 2013-2015, with the help of EU structural funding. The goals of the Centre were to collect data from different state agencies to analyse the associations between morbidity and environmental factors; to conduct risk assessments and health impact analyses; and to develop evidence-based policy proposals concerning environmental health [60]. Due to the of lack of resources, the work of the Centre on comprehensive risk and vulnerability analyses has stopped.

The Estonian Rescue Board, in collaboration with Health Board [61], conducts risk analyses for emergency situations (Table 1). However, most of the analyses do not consider climate change when assessing the probability and impact of events. The Internal Security Development Plan 2015-2020 [58] identified, as a problem, the lack of a common environment for analyses of the sustainability of essential services, and of phenomena and events with impacts on the living environment; together, these make the timely prediction of needs impossible. An official from the Ministry of the Interior stated in an interview the need to make the compilation of risk analyses more efficient (29 April 2015): "We would like to create a situation where the risk analysis is more frequent, based on the needs, in other words, when there is a need for a more frequent analysis than after every two years, then it is done..."

\subsubsection{Protective Measures and Responses}

Emergency plans specify administration structures during emergency situations, the tasks of participating institutions, and procedures for information exchange and for notifying the public in case of large-scale forest or landscape fires, storms, floods in densely populated areas, and epidemics [62-65]; heatwaves are excluded. Under the coordination of Health Board, health service providers are expected to deliver health services to those affected $[59,61,64,65]$. The weak capacity of the Health Board to manage emergency situations was mentioned by a representative of the Rescue Board (7 June 2015): "Only the police and rescue services have a real operational capacity currently in Estonia, the rest who should run the situation, like the Health Board or Environmental Board, only do it declaratively since they have no capacity, experience or structure to speak of today." Risk analyses compiled by the Health Board [66] noted that microclimates in hospital wards and work premises are likely to deteriorate as a consequence of warmer weather, because most hospitals lack air conditioners. An official from the Ministry of the Interior (29 April 2015) and one from the Health Board's medical bureau (25 May 2015) noted that hot weather plans as not being necessary because: "We do not have such extreme conditions as a result of which hospitals should start rearranging their work." Family physicians, hospitals, and ambulance services operate under private law, and their responsibilities and preparedness competences in case of emergency events, like extreme weather, have not been analysed nor regulated [62].

According the Internal Security Development Plan 2015-2020 [58], plans for managing emergency situations are not tested on a regular basis, as required by law (RT I, 2009, 39, 262). For example, during a national exercise "Snowstorm 2010" that took place in the January of 2010, Padaorg valley 
was mentioned as an area of greatest risk. In the end of the same year, when snowstorm Monica struck Estonia, hundreds of people were left to the elements in Padaorg. Although according to the law, the organisation of exercises and training should be the responsibility of the ministry that is responsible for the emergency, the reality is that national exercises have only been organised by the Ministry of Interior [67].

The interviews also revealed a need to address the issue of "grassroots level applications" to create possibilities for people to protect their health in everyday life. In the case of more frequent extreme weather in the future, the most vulnerable, including the elderly, the chronically ill, or mentally disabled, require special attention from social care and primary healthcare providers. Although social care professionals possess vital information on the location and specific needs of the most vulnerable, they have not been engaged in the process of adaptation (interview with an expert in social care 4 March 2015).

Response measures targeted at individuals during a crisis mainly focus on information-sharing on the web about health risks and preventative measures and instructions on behaviour, and do not consider practical arrangements or infrastructure (Table 1). Web-based information-sharing is limited because not all vulnerable groups have access. According to a Health Board official (7 May 2015), recommendations for the population, including risk groups, in the case of extreme hot weather, are published on the Health Board's website; however, there was no money for published brochures. An official from the Ministry of Environment (21 May 2015): "What needs to be improved is the notification of the public, early warning of the climate change health risks." A family physician (7 July 2015) criticised the whole information-based approach for adverse impact prevention: "Let me give you an example, even if we have info on the radio on the dangerously high UV-factor, people still go to the beach to get tanned."

\subsection{Explanations for the Current Situation with Respect to Health Adaptation}

There are questions about how the situation evolved in which goals concerning climate change health effects have been set only in the fields of environment and internal security; why monitoring climate parameters are fragmentary and do not cover all the important factors for assessing health effects; why the quality of risk analyses are disputed; why rescue and private health service providers and social care cooperation procedures have not been developed; and why exercises to increase the capacity to cope with extreme weather conditions are irregular and not very effective.

\subsubsection{The Inner Functioning of the State Apparatus Influences the Adaptation Activities}

The absence of an integrated approach to climate adaptation can be explained by the nature of the administrative culture of the institutions involved in the Estonian health system. On the one hand, adaptation policies are influenced by an understanding of the necessity of state intervention (or the lack thereof) and, on the other hand, the manner of making decisions and their transparency. A prevalent viewpoint is that individuals can adapt to climate change because it occurs over long time periods, so preparedness only needs to be ensured for extreme changes. As stated by a climate expert (29 April 2015): "We need the support of the state first and foremost when health effects have occurred as a result of short and abrupt changes. For certain, human body has the ability to adapt to long-term changes." Likewise, the majority of the interviewees found that state regulations are sufficient, and that increasing the readiness of people to cope with changing weather patterns is all that is needed. As one official from the Ministry of the Interior said (29 April 2015): "The readiness of people to cope has decreased. This should be taught from early on."

In coping with extreme weather events, transparency in decision-making was called into question. Interviews pointed out that although shaping policies is open to different parties, decisions in the area of health and rescue are made by a small closed group. The officials pointed out that sometimes government decisions come without explanation as to what was the motive or evidence behind a decision. As a specialist in environmental health from the Ministry of Social Affairs (4 May 2015) said: "Today such decisions are made in politics the background of which is not known even to us-no matter have the 
scientists or experts been involved or not." There was no evidence supporting the hypothesis that there is a change in the climate-related norms of the political actors in Estonia or for growing support for climate adaptation policy.

The administrative architecture is important for monitoring climate change-related health effects and assessing the readiness to cope with emergencies; these are lagging due to the dispersal of responsibilities across institutions. A specialist in public health discussed the challenge of not having an owner of the issue of the health risks of climate change: "Climate health effects, as environmental health in general, is a highly cross-sectoral phenomenon and nobody really wants to claim the problems and take responsibility for the area." A specialist in environmental health in the Ministry of Social Affairs (4 May 2015) brought out problems in distributing resources in connection with the application of measures and executing control: "The Ministry of the Environment has the money and the Ministry of Social Affairs has the problems, however, the ministry will not allocate money to solve the problems. The fragmentation of the area between the ministries would not even be a problem if there was clarity as to which ministry should be paying for solving the problem."

Distributing responsibilities between ministries with insufficient cooperation between them results in problems when dealing with emergency situations associated with climate change, as was pointed out by a representative of the Rescue Board (7 June 2015): "Each ministry has their own plans for coping in different situations, but there is no general plan." A representative of the Rescue Board (18 June 2015) said: "Currently, the Ministry of the Interior is the coordinator of crises situations and other ministries do not want to come along in this matter. The Ministry of the Interior does not have the means to force other ministries either. This is why such freewheeling exists. Since the state has not given any direct guidelines the departments just see how they can manage." A family physician (7 May 2015) commented on the ability of healthcare to react in case of emergency situations: "Everybody is doing what comes to mind. There is no uniformly controlling agency to whom to turn to. The tasks and who precisely is responsible for what has not been clearly determined. This is a very topical problem." A representative of Rescue Board said: "It would be complicated to get the hospitals and doctors behind one table, to map their resources and situation, because they are private bodies. One can only assume that when something happens that would exceed the capacity of a local hospital, other hospitals would accept the patients; however, there is actually no certainty in this matter." The issue of silos of primary healthcare, emergency situations, and social care was also stressed by a city medical officer (12 June 2015): "Now when the family physicians are no longer part of local governments and the communication takes place through Ministry of Social Affairs, the health care part is distancing itself from the local governments' health adaptation issues."

One of the factors influencing the administrative capability to cope with climate change on the state level is the scarcity of the necessary expertise. A separate programme for environmental health to address adaptation issues was not considered necessary. There is almost no continuing medical training in environmental health for physicians. Climate change-related health risks are an unknown territory for social care professionals. As an expert in social work (4 March 2015) explained: "A social worker or caretaker does not have the knowledge about what kind of weather conditions present danger and how to prepare a ward. The current activities are all a creative effort on the spot."

Lack of financing has inhibited monitoring, integrating databases to assess health effects and rescue necessities, and diversifying information systems. Creating a common pool of resources and synergies by coordination of information systems is resisted for a paradoxical reason mentioned by an official from the Ministry of the Interior (29 April 2015): “We are, nevertheless, a poor country. There is a fight in departments for money and for each individual." Poor preparedness of medical infrastructure and staff are explained by a lack of financing and prioritisation. The interviewed medical workers stressed the inadequacy of human resources to cope with climate-related disease outbreaks. As a family physician (7 May 2015) explained: "As for today, we don't have extra resources in case of an outbreak." At the same time, some officials claimed there are insufficient human resources to ensure the capability to deal with climate change-related health risks. An official from the Ministry of the Interior (29 April 2015) said: "Climate change is currently highly unlikely and the effect climate change has does not exceed the usual 
capability of the hospitals; we do not treat this as a likely emergency right now." This also explains the insufficient investment into cooling systems for hospitals and care homes.

\subsubsection{Adaptation Activities Influenced by the External Pressure Factors of the State Apparatus}

The lack of public interest may reduce the pressure on health systems to address climate change-related health risks. An Eurobarometer survey [68] confirms that, in comparison with the rest of Europe, Estonia has the fewest numbers of people who consider climate change as a very serious problem. Analyses of the population-based survey focused on people with strong beliefs that state measures are necessary to reduce the health risks from climate change (respondents scores $4-5$ on a five-point-scale, ranging from strong disagreement (1) to strong agreement (5), accounting for $30 \%$ (301) of respondents). There are significantly $(p<0.05)$ more women, ethnicities other than Estonians, and urban residents with high interest in adaptation measures (Appendix D). The level of interest does not differ significantly by age, educational group, or level of individual self-rated health.

We identified factors explaining high interest in measures for reducing the health risks of climate change using logistic regression. The base model predicting demand for measures included gender, age, education, home language, and self-rated health status. Table 2 shows that Estonian-speakers had a 0.61 (95\% CI 0.43-0.86) lower odds of requesting measures than individuals speaking Russian or other languages. When adding the possible predictors of demand to the base model one-by-one, no effect was seen between the trust in institutional efficacy in taking care of the healthfulness of the environment and demand for measures. Compared to individuals with high worry, individuals with low worry had $0.57(0.37-0.88)$, and individuals with medium worry had $0.58(0.38-0.88)$ lower odds of demanding measures. The odds of demanding measures increased by $1.24(1.06-1.45)$ when the perceived exposure to extreme weather events increased by one degree on a five-point-scale.

Table 2. Association between factors and the belief in need for measures to reduce the health risks from climate change in Estonia, odds ratios (95\% CI).

\begin{tabular}{llc}
\hline \multicolumn{1}{c}{ Base Model } & Sig. & Exp(B) \\
\hline Gender, man (ref woman) & 0.79 & $0.96(0.68-1.34)$ \\
Age, 20-34 (ref 55-75) & 0.19 & $0.73(0.46-1.17)$ \\
Age, 35-54 (ref 55-75) & 0.10 & $0.71(0.48-1.06)$ \\
Education, primary (ref higher) & 0.84 & $1.08(0.50-2.33)$ \\
Education, secondary (ref higher) & 0.57 & $0.90(0.62-1.30)$ \\
Home language, Estonian (ref Russian or other) & 0.01 & $0.61(0.43-0.86)$ \\
Self-rated health status & 0.71 & $0.96(0.79-1.18)$ \\
\hline Social and psychological factors * & & \\
\hline Belief in state institutions taking care of the & 0.52 & $0.94(0.79-1.18)$ \\
healthfulness of living environment & & \\
\hline Worry about health effects from environment on & & $0.57(0.37-0.88)$ \\
personal and family health & 0.01 & $0.58(0.38-0.88)$ \\
\hline Low (ref high worry) & 0.01 & $1.24(1.06-1.45)$ \\
Medium (ref high worry) & 0.01 & \\
Exposure to extreme weather events & & \\
* Logistic regression was adjusted for gender, age, education, home language, and self-assessed health status.
\end{tabular}

The opinion that the health risks of climate change are a comparatively less important concern for Estonian society is also reflected in the (lack of) political debate and administrative prioritisation. This was brought out in key expert interviews. All the respondents started the interview with a recognition that they do not believe that climate in Estonia will start changing considerably, and that there is not enough evidence to confirm that climate change is occurring. For example, an official from the Ministry of the Interior (29 April 2015) said: "The numbers do not show that the climate would change dramatically in Estonia; we have no facts to support that today."

One of the most important factors that has kept public and political salience low is the insufficiency of corroborating scientific evidence that climate change affects health. Up to 2015, there were very 
few studies in Estonia on the interaction between climate change, environmental factors, and health indicators. Limited governmental resources have forced the state to set priorities; environmental health is not one of them. A public health specialist (8 May 2015) emphasised: "Unfortunately, environmental health is not a priority and therefore there is no state funding available." Paradoxically, the officials consider the role of scientific research important in making decisions. As a specialist in environmental health from the Ministry of Environment (4 May 2015) said: "We do nothing just because of gut feeling. We will not contribute the resources if there are no prognoses or studies made. At least when a change has been initiated by us, there must always be a scientific explanation behind it."

The shortage of expertise in this area is also suggested by the fact that Estonia does not train specialists in environmental health, and in medical school, the topic is covered in only one subject. A public health specialist (8 May 2015) stated: "We have many specialists on environment in different universities in Estonia, but in none of them has a course on environmental health in which climate change and its actual health effects would be clarified for the future decision makers." The National Health Plan 2009-2020 [38] includes measures for training of health effect assessment specialists and for collecting environmental health related knowledge. So far, there are no resources to support this.

The key experts do not see commercial interests as having an impact on the design or implementation of health adaptation policies. Increasing introductions of viruses could interest new product development in pharmaceutical companies. For example, tick-borne encephalitis can be prevented by vaccination. According to a family physician (7 May 2015), it is simply a matter of time until the pharmaceutical companies "get wind of $i t^{\prime \prime}$ and start gathering support for the national vaccination programme.

\subsubsection{International Pressures}

The lack of public interest may reduce the state-level policies that are often influenced by international agreements or the experiences of neighbouring countries. A key factor in the development of Estonian health adaptation policies is European Union regulations. Therefore, developing a national strategy for health adaptation is based on the EU strategy on adaptation to climate change [43]. When developing policies in the area of safety, according to an official from the Ministry of the Interior, the examples of Sweden, Finland, and Germany were taken into account (official from the Ministry of the Interior 20 April 2015). However, the progressive examples of Sweden and Finland were not considered.

In addition to the need to develop an adaptation strategy, the interviewees considered the influence of the EU to be an important example of the demand to finance and monitor environmental factors. Thus, a public health specialist (8 May 2015) emphasised: "The European Union has a huge influence in improving for example environmental monitoring, since as a condition of the accession to the EU, Estonia has had to introduce several amendments to the laws and that effect is only positive, since the efficiency of monitoring is on the increase as a result of it." For example, the purpose of the "Report on the risks of flooding" is to map flood-prone areas in Estonia using observations according to Articles 4 and 5 of the EU Floods Directive [69].

\section{Discussion}

Our research clarified the factors determining the preparedness of the health system in Estonia to manage the health risks of climate change. The study was conducted in 2015, when health adaptation had not been legally defined. The material analysed was used as background material for compiling the strategy "Climate Change Adaption Development Plan until 2030" that was ratified by the Estonian parliament in 2017 [70]. A “Climate Change Adaption Development Plan's Action Plan for 2017-2020" was subsequently agreed upon. However, the resources dedicated for the action plan were a magnitude smaller than what was proposed [71]. Therefore, many of the problems raised in the study remain to be addressed. Our analyses take an in-depth look at one country, Estonia. The lessons learned could be of relevance for other countries with similar Eastern European backgrounds. In some Eastern 
European countries (e.g., Poland), climate change adaptation and mitigation are taken seriously at the city level [25]. However, Eastern European countries, including Estonia, fall far behind Finland, Sweden, and the United Kingdom in adaptation planning and implementation.

The policy innovation literature, e.g., [4,72] offers some clues as to the circumstances under which adaptation policies emerge, e.g., bringing out the role of leadership and the state's participation in international organisations. However, the literature stops short in giving an integrated look at the drivers behind implementation, monitoring, and protective responses. We took a broader look at the health systems functioning and the variety of drivers shaping its effectiveness and equality in provision. An in-depth case study allowed exploration of the mechanisms behind the adoption and implementation of adaptation policies, including the broader perspective of health systems, particularly prevention, healthcare provision, and rescue services.

The WHO Operational Framework foresees that for effective policymaking activities, policymakers and other stakeholders require accurate, timely information on health and health system conditions. However, up until the initiation of baseline studies for a climate adaptation strategy pursuant to the EU Directive [15], there had been no studies on climate change and related health systems functioning. Our analyses confirm the findings by Massey et al. [23] that external drivers, primarily, the centrality of EU is required for the diffusion of adaptation policies across Europe. EU institutions are important driving forces for gathering information, especially in improving monitoring and early warning systems.

It has been argued that the "EU values" on climate change are not internalised by the political actors in Central and Eastern Europe [25]. The analyses in this paper highlight several key impediments for why health systems have not fully adopted these ideas. One is the style of regulation. The market liberal state approach characteristic of environmental health governance in Estonia can dissociate responsibilities with the "lean state" rhetoric [18]. The overruling perspective among policymakers is that if climate change occurs at all, then people should be able to cope with the long-term effects by themselves. Such a perspective can be explained by limited economic capacity and the lack of evidence. This dissociation of responsibilities is understandable as the evidence pointing to the need for intervention is scarce, and longer-term planning based on projections of the health risks of climate change is limited. The tendency of turning a "blind eye" towards policy problems by limiting investments in monitoring and inspection also occur in other environmental health issues [18]. We may assume that health systems in other small countries with dispersed human, financial, and political resources may lack the resources necessary for adaptive capacity [22] to deal with what is still often considered as an avant-garde issue of climate change risks.

Even if the capability to cope during acute situations exists, there is no certainty as to the extent to which family physicians and hospitals operating under the private law would be ready for extreme events. Maintaining an informed and effective practitioner workforce is a critical challenge for health systems grappling with extreme events [13], however, no contingency plan has been elaborated for hospitals. Limited preparation and the state approach of minimal interference has important implications for the safety of the most vulnerable population groups, including elderly and minority groups.

Our results highlight the significance of the regulatory architecture and the related allocation of responsibilities. Climate change-related health risks are highly cross-sectoral, which means that other state departments are expected to assume primary responsibility. In extreme weather conditions, healthcare systems and rescue services will indeed cope within the limits of their competences, but in case of more complex issues, prevention and timely responses are inhibited by the lack of cooperation between rescue and social services, and healthcare providers. Also, for information-gathering, monitoring of some parameters or vulnerable groups is organised separately, fragmented between institutions. Fragmentation inhibits the integrated assessment of climate change-related health and related risks and vulnerabilities. Furthermore, lack of coordination and integration impedes accessing a range of possible solutions. The process of mainstreaming a policy issue (also called 
policy integration [73]) through the integration of adaptation policy and measures into ongoing national sectorial planning is expected to increase policy coherence, minimise contradictory policies, and capture the opportunities for synergistic efforts in terms of increased adaptive capacity [74]. However, developing cross-sectorial policy goals becomes more demanding with an increase in the number of affected institutions and interests [75,76]. A solution addressing the institutional and organisational dimension of the problem would be to appoint a responsible institution that could facilitate policy integration in-between existing policy pillars. Attempts at mainstreaming are also more likely when the issue receives political attention [24]. The EU Climate Adaptation Strategy has been an important force to increase the political salience of the topic. However, this has yet to translate into actual better coordination between the institutions.

Our analysis shows the societal and institutional silencing of the health risks of climate change. Institutional responses constitute important influences on people's perceptions [77], and the implementation of adaptation measures require some degree of demand from citizens [78,79]. The low level of worries and attention to climate change adaptation measures can be explained through the limited "pool of worries" hypothesis, and the tendencies of attenuation of risk in countries preoccupied with socioeconomic instability. With the increase in income levels, the East of Europe countries are expected to increase their concern with respect to climate change [80,81]. Although there is an increase in levels of concern in Eastern member states, including Estonia, instead of these countries "catching up" with the levels of concern of southern and northern EU countries, the Eurobarometer studies show an increase in the relative difference between the average levels of concern in these groups of countries [68].

Low level of engagement with adaptation has been attributed to a lack of knowledge of climate change and related adaptation issues [82,83]. Although experience with weather-related phenomena may give rise to a perceived need for adaptation action [84-86], Estonia has yet to experience any major weather extremes (except for a major heatwave in 2010 [87]. This may have impeded awareness of the risks amongst the public. The low demand for health adaptation may also be explained by the general population being used to relatively extreme weather over four seasons (a few hot weeks are warmly welcomed). Further, the geographical size of the country may play a role, as the small size of the country decreases the chances of anything happening, leaving an impression that climate-related events that happen in other, even close-by countries, do not affect our safety and wellbeing. It has been argued that extraordinary storms and heatwaves can result in a focus on the current emergency, leaving the long-standing risks unattended [20]. However, the Estonian case indicates that increased experience with attention-grabbing extreme events in the northeastern parts of Europe could bring to the fore the need to consider long-term climate trends, and risks for health and health systems.

The occurrence of extreme weather events, coupled with research projecting that these are likely to increase in frequency and severity, resulting in increasing costs in the future, motivates richer states [23]. In the case of Estonia, an upper-middle income country, the lack of public and political salience means research of climate change-related health effects is less of a priority. The associated lack of evidence, in turn, may inhibit raising public awareness and efforts to establish health adaptation goals and implement policies and programs, including increasing individual and community-based capacities to respond to emergencies. Recent projections indicate substantial increases in summer temperatures by the end of the century over central and Eastern Europe [88], along with projected increases in pollution levels (near-surface ozone and aerosol particles) [89]. Health risks will increase under these projections, unless proactive adaptation is undertaken.

Ethnic minorities (mainly Russian-speaking) and city-dwellers are more worried about climate change, and express higher demand for protective measures. Their concerns can be explained by their social status, and the perceived level of control a person has over one's physical or psychological wellbeing. As shown also in the literature on risk perception among minority groups [90], the demand for measures is high among individuals with weakened positions, and who, in general, may have restricted ability to influence decision-making. This has further implications for managing the 
vulnerability of minority groups. Their perceived inhibited access to informal and institutional support may be an indication of actual vulnerability, but also a lack of awareness of support networks. As a novel finding, respondents in urban areas expressed higher demand for measures for coping with the health risks of climate change. A possible explanation for the urban dwellers' higher demand for protective measures could be attributed to their dependence on urban expert systems and infrastructures that may make city dwellers feel more vulnerable, with a general sense of higher exposure to extreme weather events. In rural areas, individuals have lower expectations from the state, being situated further away from expert systems; they have maintained skills to cope with current extreme weather events, but may not be prepared for future, more extreme events.

\section{Conclusions}

The study shows the significance of the EU pressures for aligning the health systems of a small country, like Estonia, with the climate adaptation goals of building resilience to future increases in, e.g., projected storminess and length of heatwaves. However, the effect of these external pressures remains short-lived, when the political salience of climate change and the related political will is low to mainstream climate change into policies, and to invest scarce resources in adaptation policy programmes, monitoring, and protective responses. Although efforts are being made in emergency preparedness and rescue, which, as a co-benefit, increase the ability to cope with the health risks of climate-related extreme events, the state has limited avenues for pressuring the private domains of primary care and hospitals. There are significant opportunities to gain synergistic benefits from conducting risk and vulnerability analyses, and from building community resilience through mainstreaming climate change over related policy fields, including rescue services, health, environment, social care, and even education. In a situation where there is lack of issue ownership, policy integration and mainstreaming could be facilitated by appointing a responsible institution. Institutional responses resonate with people's perception and the demand for adaptation measures. As characteristic of a small health system, the shortage of regionally specific scientific assessments and lack of pressure from other organised interest groups, attenuate the social and political urgency for adaptation. Nevertheless, growing experience with extreme weather events, particularly among increasing urban and minority populations who are detached from traditional coping strategies, may increase demand for the provision of state support for health adaptation.

Author Contributions: K.O. conceived the research questions and design; conducted the analysis and did most of the writing of the manuscript; M.T. conducted expert interviews and participated in their analysis; K.L.E. provided advice on the data analysis and helped in writing the manuscript; H.O. conducted the population-based survey and contributed to writing the manuscript.

Funding: K.O.'s work on the preparation of this article was supported by the HEALTHDOX project (MSHUH14155) financed by NORFACE Programme. H.O.'s work on the preparation of this article was supported by the Estonian Ministry of Education and Research grant IUT34-17.

Conflicts of Interest: The authors declare no conflict of interest.

\section{Appendix A}

Interviewed experts:

1. Expert on social work (4 March 2015)

2. Local government official (10 March 2015)

3. Tartu City Government official (17 March 2015)

4. Environmental health scientist (20 April 2015)

5. Official from the ministry of the Interior (29 April 2015)

6. Climate expert (29 April 2015)

7. Environmental health specialist, Ministry of Social Affairs (4 May 2015)

8. Official from the Estonian Environmental Research Centre (4 May 2015) 
9. Family physician (member of the managing board, Association of Family Physicians) (7 May 2015)

10. Health Board official (7 May 2015)

11. Public health specialist (8 May 2015)

12. Official from the Ministry of the Environment (21 May 2015)

13. Representative of a hospital (member of managing board) (4 June 2015)

14. City medical officer (12 June 2015)

15. Representative of volunteer rescue service providers (16 June 2015)

16. Representative of Rescue Board (Lääne päästekeskus) (18 June 2015)

17. Official from the Health System Development Department, Ministry of Social Affairs (19 June 2015)

18. Chief specialist from the Environmental Health Research Centre, Health Board (27 May 2015)

19. Official from the Health Board's medical bureau (25 May 2015)

20. Official from Pärnu City Government (26 August 2015)

21. Official from Government Office (27 August 2015)

\section{Appendix B}

Interview guide:

- What do you think about the climate change and its health effects?

- Health risks in the world/Estonia

- Future trends

- How would you assess health systems functioning to cope with CC effects on health?

- Sufficiency of regulations, programmes

- Monitoring and information gathering (prognoses, risk analyses)

- Protective responses, prevention

- What could be the key drivers/impediments on (a) tailoring programmes, measures, and (b) their implementation for CC health adaptation, (c) gathering information? Assess the role of ...

yourself as an expert; public salience, NGOs, private companies, scientific groups, international organisations

- state officials, their competences and resources, regulatory style (and size), architecture (dispersion of responsibilities).

\section{Appendix C}

Table A1. Questionnaire items on key variables.

\begin{tabular}{|c|c|c|c|c|c|c|}
\hline \multirow[t]{2}{*}{1} & \multirow{2}{*}{\begin{tabular}{l}
\multicolumn{1}{c}{ Personal Exposure } \\
Please rate on a scale of $1-5$ your exposure \\
to extreme weather events
\end{tabular}} & \multicolumn{2}{|c|}{ No Exposure } & \multicolumn{3}{|c|}{ Extreme Exposure } \\
\hline & & 1 & 2 & 3 & 4 & 5 \\
\hline \multirow[t]{2}{*}{2} & Personal worry & \multicolumn{2}{|c|}{ No exposure } & & \multicolumn{2}{|c|}{ Extreme exposure } \\
\hline & $\begin{array}{l}\text { In general, how worried are you about the } \\
\text { health risks posed to you and your family } \\
\text { by your residential environment? }\end{array}$ & 1 & 2 & 3 & 4 & 5 \\
\hline \multirow[t]{2}{*}{3} & Belief in need for measures & \multicolumn{2}{|c|}{ No exposure } & & \multicolumn{2}{|c|}{ Extreme exposure } \\
\hline & $\begin{array}{l}\text { Measures against climate change related } \\
\text { risks are urgently needed }\end{array}$ & 1 & 2 & 3 & 4 & 5 \\
\hline \multirow[t]{2}{*}{4} & Belief in institutional efficiency & \multicolumn{2}{|c|}{ No exposure } & & \multicolumn{2}{|c|}{ Extreme exposure } \\
\hline & $\begin{array}{l}\text { I trust that the authorities will take care of } \\
\text { the healthfulness of my living environment }\end{array}$ & 1 & 2 & 3 & 4 & 5 \\
\hline
\end{tabular}




\section{Appendix D}

Table A2. Low and high demand for state intervention to mitigate climate change CC health effects per demographic and self-rated health, and group comparisons.

\begin{tabular}{|c|c|c|c|c|}
\hline & Low Demand, n (\%) & High Demand, n (\%) & $\mathrm{Chi}^{2}$ & $p$ Value \\
\hline Gender & & & 3.11 & 0.08 \\
\hline Male & $320(72.7)$ & $120(27.3)$ & & \\
\hline Female & $377(67.6)$ & $301(32.4)$ & & \\
\hline Age & & & 2.47 & 0.29 \\
\hline Age, 20-34 & $110(67.9)$ & $52(32.1)$ & & \\
\hline Age, 35-54 & $211(69.2)$ & $94(30.8)$ & & \\
\hline Age, 55-75 & $109(62.3)$ & $66(37.7)$ & & \\
\hline Education & & & 0.03 & 0.98 \\
\hline primary & $23(65.7)$ & $12(34.3)$ & & \\
\hline secondary & $262(67.2)$ & $128(32.8)$ & & \\
\hline higher & $143(66.8)$ & $71(33.2)$ & & \\
\hline Home language & & & 13.86 & 0.00 \\
\hline Estonian & $496(73.6)$ & $178(26.4)$ & & \\
\hline Russian or other & $201(62.0)$ & $123(38.0)$ & & \\
\hline Place of residence & & & 9.93 & 0.00 \\
\hline Urban & $473(66.9)$ & $234(33.1)$ & & \\
\hline Rural & $224(77)$ & $67(23)$ & & \\
\hline Self-rated health status & & & 8.69 & 0.12 \\
\hline Very good & $52(71.2)$ & $21(28.8)$ & & \\
\hline Good & $299(72.7)$ & $112(27.3)$ & & \\
\hline Average & $277(67.6)$ & $133(32.4)$ & & \\
\hline Bad & $59(69.4)$ & $26(30.6)$ & & \\
\hline Very bad & $6(75.0)$ & $2(25.0)$ & & \\
\hline
\end{tabular}

\section{References}

1. Sellers, S.; Ebi, K.L. Climate change and health under the shared socioeconomic pathway framework. Int. J. Environ. Res. Public Health 2017, 15, 3. [CrossRef] [PubMed]

2. Watts, N.; Adger, W.N.; Agnolucci, P.; Blackstock, J.; Byass, P.; Cai, W.; Chaytor, S.; Colbourn, T.; Collins, M.; Cooper, A.; et al. Health and climate change: Policy responses to protect public health. Lancet 2015, 386, 1861-1914. [CrossRef]

3. Smith, K.R.; Woodward, A.; Campbell-Lendrum, D.; Chadee, D.D.; Honda, Y.; Liu, Q.; Olwoch, J.; Revich, B.; Sauerborn, R. Human health: Impacts, adaptation, and co-benefits. In Climate Change 2014: Impacts, Adaptation, and Vulnerability. Part A: Global and Sectoral Aspects. Contribution of Working Group II to the Fifth Assessment Report of the Intergovernmental Panel on Climate Change; Field, C.B., Barros, V.R., Dokken, D.J., Mach, K.J., Mastrandrea, M.D., Bilir, T.E., Chatterjee, M., Ebi, K.L., Estrada, Y.O., Genova, R.C., et al., Eds.; Cambridge University Press: Cambridge, UK, 2014; pp. 709-754.

4. Jordan, A.; Huitema, D. Innovations in climate policy: The politics of invention, diffusion, and evaluation. Environ. Politics 2014, 23, 715-734. [CrossRef]

5. Austin, S.E.; Biesbroek, R.; Berrang-Ford, L.; Ford, J.D.; Parker, S.; Fleury, M.D. Public health adaptation to climate change in oecd countries. Int. J. Environ. Res. Public Health 2016, 13, 889. [CrossRef] [PubMed]

6. Hess, J.J.; McDowell, J.Z.; Luber, G. Integrating climate change adaptation into public health practice: Using adaptive management to increase adaptive capacity and build resilience. Environ. Health Perspect. 2012, 120, 171-179. [CrossRef] [PubMed]

7. Bowen, K.J.; Ebi, K.L. Governing the health risks of climate change: Towards multi-sector responses. Curr. Opin. Environ. Sustain. 2015, 12, 80-85. [CrossRef] 
8. Amundsen, H.; Berglund, F.; Westskog, H. Overcoming barriers to climate change adaptation-A question of multilevel governance? Environ. Plan. C Gov. Policy 2010, 28, 276-289. [CrossRef]

9. Austin, S.E.; Ford, J.D.; Berrang-Ford, L.; Araos, M.; Parker, S.; Fleury, M.D. Public health adaptation to climate change in canadian jurisdictions. Int. J. Environ. Res. Public Health 2015, 12, 623-651. [CrossRef] [PubMed]

10. Roose, A. Climate changes-How to adapt? Publ. Inst. Geogr. Univ. Tartu 2015, 112, 6-19.

11. Rothstein, H.; Demeritt, D.; Paul, R.; Beaussier, A.-L.; Wesseling, M.; Howard, M.; de Haan, M.; Borraz, O.; Huber, M.; Bouder, F. Varieties of risk regulation in europe: Coordination, complementarity and occupational safety in capitalist welfare states. Socio-Econom. Rev. 2017, mwx029. [CrossRef]

12. Hood, C.; Rothstein, H.; Baldwin, R. The Government of Risk: Understanding Risk Regulation Regimes; Oxford University Press: New York, NY, USA, 2001.

13. World Health Organization. Operational Framework for Building Climate Resilient Health Systems; World Health Organization: Geneva, Switzerland, 2015.

14. Kieny, M.P.; Bekedam, H.; Dovlo, D.; Fitzgerald, J.; Habicht, J.; Harrison, G.; Kluge, H.; Lin, V.; Menabde, N.; Mirza, Z.; et al. Strengthening health systems for universal health coverage and sustainable development. Bull. World Health Organ. 2017, 95, 537-539. [CrossRef] [PubMed]

15. Commission of the European Communities. White Paper-Adapting to Climate Change: Towards a European Framework for Action; COM: Brussels, Belgium, 2009.

16. Hildén, M. Evaluation, assessment, and policy innovation: Exploring the links in relation to emissions trading. Environ. Politics 2014, 23, 839-859. [CrossRef]

17. Hildén, M.; Jordan, A.; Rayner, T. Climate policy innovation: Developing an evaluation perspective. Environ. Politics 2014, 23, 884-905. [CrossRef]

18. Orru, K.; Rothstein, H. Not 'dead letters', just 'blind eyes': The europeanisation of drinking water risk regulation in estonia and lithuania. Environ. Plan. A Econ. Space 2015, 47, 356-372. [CrossRef]

19. Vihalemm, T.; Keller, M.; Kiisel, M. From Intervention to Social Change: A Guide to Reshaping Everyday Practices; Ashgate: Surrey, UK, 2015.

20. Knaggård, Å. What do policy-makers do with scientific uncertainty? The incremental character of swedish climate change policy-making. Policy Stud. 2014, 35, 22-39. [CrossRef]

21. Howlett, $\mathrm{M}$. Why are policy innovations rare and so often negative? Blame avoidance and problem denial in climate change policy-making. Glob. Environ. Chang. 2014, 29, 395-403. [CrossRef]

22. Gupta, J.; Termeer, C.; Klostermann, J.; Meijerink, S.; van den Brink, M.; Jong, P.; Nooteboom, S.; Bergsma, E. The adaptive capacity wheel: A method to assess the inherent characteristics of institutions to enable the adaptive capacity of society. Environ. Sci. Policy 2010, 13, 459-471. [CrossRef]

23. Massey, D.; Chaboyer, W.; Aitken, L. Nurses' perceptions of accessing a medical emergency team: A qualitative study. Aust. Crit. Care Off. J. Confed. Aust. Crit. Care Nurses 2014, 27, 133-138. [CrossRef] [PubMed]

24. Rauken, T.; Mydske, P.K.; Winsvold, M. Mainstreaming climate change adaptation at the local level. Local Environ. 2015, 20, 408-423. [CrossRef]

25. Reckien, D.; Salvia, M.; Heidrich, O.; Church, J.M.; Pietrapertosa, F.; De Gregorio-Hurtado, S.; D'Alonzo, V.; Foley, A.; Simoes, S.G.; Krkoška Lorencová, E.; et al. How are cities planning to respond to climate change? Assessment of local climate plans from 885 cities in the eu-28. J. Clean. Prod. 2018, 191, 207-219. [CrossRef]

26. Gupta, S.; Harnisch, J.; Barua, D.C.; Chingambo, L.; Frankel, P.; Vazquez, R.J.G.; Gomez-Echeverri, L.; Haites, E.; Huang, Y.; Kopp, R.; et al. Cross-cutting investment and finance issues. In IPCC Working Group III AR5.; Cambridge University Press: Cambridge, UK, 2014.

27. Bowen, K.J.; Ebi, K.; Friel, S.; McMichael, A.J. A multi-layered governance framework for incorporating social science insights into adapting to the health impacts of climate change. Glob. Health Action 2013, 6, 21820. [CrossRef] [PubMed]

28. Tosun, J.; Lang, A. Policy integration: Mapping the different concepts. Policy Stud. 2017, 38, 553-570. [CrossRef]

29. Ollila, E. Health in all policies: From rhetoric to action. Scand. J. Public Health 2011, 39, 11-18. [CrossRef] [PubMed]

30. May, P.J.; Jochim, A.E.; Sapotichne, J. Constructing homeland security: An anemic policy regime. Policy Stud. J. 2011, 39, 285-307. [CrossRef] 
31. Spence, A.; Venables, D.; Pidgeon, N.; Poortinga, W.; Demski, C. Public Perceptions of Climate Change and Energy Futures in Britain; Technical Report; School of Psychology: Cardiff, UK, 2010.

32. Kingdon, J.W. Agendas, Alternatives, and Public Policies; Longman: Boston, MA, USA, 2011.

33. Portier, C.; Thigpen Tart, K.; Carter, S.; Dilworth, C.; Grambsch, A.; Gohlke, J.; Hess, J.; Howard, S.; Luber, G.; Lutz, J.; et al. A Human Health Perspective on Climate Change: A Report Outlining the Research Needs on the Human Health Effects of Climate Change; Environmental Health Perspectives/National Institute of Environmental Health Science: Durham, NC, USA, 2010.

34. Wardekker, J.A.; de Jong, A.; van Bree, L.; Turkenburg, W.C.; van der Sluijs, J.P. Health risks of climate change: An assessment of uncertainties and its implications for adaptation policies. Environ. Health 2012, 11, 67. [CrossRef] [PubMed]

35. Braun, M. Eu climate norms in east-central europe. JCMS J. Common Mark. Stud. 2014, 52, 445-460. [CrossRef]

36. Biesenbender, S.; Tosun, J. Domestic politics and the diffusion of international policy innovations: How does accommodation happen? Glob. Environ. Chang. 2014, 29, 424-433. [CrossRef]

37. Skjærseth, J.B.; Wettestad, J. Is eu enlargement bad for environmental policy? Confronting gloomy expectations with evidence. Int. Environ. Agreem. Politics Law Econ. 2007, 7, 263-280. [CrossRef]

38. Felix, C.; Marcus, H.; James, R.; Kacper, S. Challenging the european climate debate: Can universal climate justice and economics be reconciled with particularistic politics? Glob. Policy 2014, 5, 6-14.

39. Tompkins, E.L.; Amundsen, H. Perceptions of the effectiveness of the united nations framework convention on climate change in advancing national action on climate change. Environ. Sci. Policy 2008, 11, 1-13. [CrossRef]

40. World Bank. Rural Population. Indicators. Available online: https://data.worldbank.org/indicator/SP.RUR. TOTL.ZS (accessed on 24 May 2018).

41. Reile, R.; Helakorpi, S.; Klumbiene, J.; Tekkel, M.; Leinsalu, M. The recent economic recession and self-rated health in estonia, lithuania and finland: A comparative cross-sectional study in 2004-2010. J. Epidemiol. Community Health 2014, 68, 1072-1079. [CrossRef] [PubMed]

42. World Health Organization. Global Health Observatory Data Repository. Life Expectancy. Available online: http:/ / apps.who.int/gho/data/view.main.SDG2016LEXv?lang=en (accessed on 24 May 2018).

43. Ministry of Environment. Proposal for Compiling Action Plan for Coping with Climate Change Till 2030; Ministry of Environment: Tallinn, Estonia, 2015.

44. Orru, K.; Hendrikson, R.; Nordlund, A.; Nutt, N.; Veeber, T.; Orru, H. Keskkonnatervis: Arusaamine Riskidest ja Motivatsioon Tervisemõjude Vähendamiseks. Keskkonnatervise Uuringute Keskus; Health Board: Tallinn, Estonia, 2015.

45. Orru, H.; Lanki, T.; Forsberg, B.; Saava, A.; Åström, D.O.; Indermitte, E.; Orru, K.; Åström, K.; Rekker, K.; Tillmann, K.; et al. Tervis. In Kliimamuutuste Mõjude Hindamine ja Kohanemismeetmete Väljatöötamine Planeeringute, Maakasutuse, Inimtervise ja Päästevõimekuse Teemas (kati); Roose, A., Ed.; Tartu Ülikool: Tartu, Estonia, 2015; pp. 162-252.

46. Giorgi, F.; Torma, C. Climate Variability and Change Over Europe. In Connections to Pollen Concentrations; ICTP: Trieste, Italy, 2015.

47. Hamaoui-Laguel, L.; Vautard, R.; Liu, L.; Solmon, F.; Viovy, N.; Khvorostyanov, D.; Essl, F.; Chuine, I.; Colette, A.; Semenov, M.A.; et al. . Effects of climate change and seed dispersal on airborne ragweed pollen loads in europe. Nat. Clim. Chang. 2015, 5, 766. [CrossRef]

48. Semenza, J.C.; Suk, J.E.; Estevez, V.; Ebi, K.L.; Lindgren, E. Mapping climate change vulnerabilities to infectious diseases in europe. Environ. Health Perspect. 2012, 120, 385-392. [CrossRef] [PubMed]

49. Mölter, T.; Schindler, D.; Albrecht, A.; Kohnle, U. Review on the projections of future storminess over the north atlantic european region. Atmosphere 2016, 7, 60. [CrossRef]

50. Ministry of Social Affairs. Action Plan of National Health Plan 2009-2020; Ministry of Social Affairs: Tallinn, Estonia, 2008.

51. Ministry of Environment. Estonian Environmental Strategy Until 2030; Ministry of Environment: Tallinn, Estonia, 2007.

52. Ministry of Environment. Estonian Environmental Action Plan 2007-2013; Ministry of Environment: Tallinn, Estonia, 2007.

53. Estonian State Weather Service. Sõnastik. Available online: http://www.ilmateenistus.ee/ilmatarkus/ sonastik/\#hiromb (accessed on 6 June 2018). 
54. Estonian State Weather Service. Sunshine. Available online: https://www.ilmateenistus.ee/kliima/climatemaps/sunshine/?lang=en (accessed on 6 June 2018).

55. Estonian State Weather Service. High-Resolution Operational Model for the Baltic Sea, Hiromb; Estonian State Weather Service: Tallinn, Estonia, 2016.

56. Air Quality Management System. Seirevõrgustik. Available online: http:/ /airviro.klab.ee/ (accessed on 8 June 2018).

57. Ministry of Interior. Emergency act. In RT I, 2009, 39, 262; Ministry of Interior: Tallinn, Estonia, 2009.

58. Ministry of Interior. Development Plan for Interior Security 2015-2020; Ministry of Interior: Tallinn, Estonia, 2015.

59. Ministry of Social Affairs. Public health act. In RT I, 1995, 57, 978; Ministry of Social Affairs: Tallinn, Estonia, 1995.

60. Health Board. Centre for Environmental Health Studies. Available online: http:/ /www.terviseamet.ee/ keskkonnatervis/keskkonnatervise-uuringute-keskus.html (accessed on 6 June 2018).

61. Ministry of Interior. The List of Emergencies According to Which a Risk Analysis and Solution Plan Will Be Composed and the Identification of the Institutions Responsible for Risk Analysis and Emergency; Ministry of Interior: Tallinn, Estonia, 2013.

62. Ministry of Interior. Plan. for Solving Emergencies Due to Storm; Ministry of Interior: Tallinn, Estonia, 2013.

63. Ministry of Interior. Plan. for Solving Emergencies Due to Flooding in Densely Populated Areas; Ministry of Interior: Tallinn, Estonia, 2013.

64. Ministry of Interior. Risk Analysis for Emergency Situations in 2013; Ministry of Interior: Tallinn, Estonia, 2013.

65. Ministry of Social Affairs. Development Plan for the Primary Care in 2009-2015; Ministry of Social Affairs: Tallinn, Estonia, 2009.

66. Health Board. Risk Analysis for Emergency Situation Related to Epidemics; Health Board: Tallinn, Estonia, 2013.

67. Ministry of Interior. Law on changing the law on emergency situations. In RT I, 2017, 1; Ministry of Interior: Tallinn, Estonia, 2017.

68. European Commission. Special Eurobarometer 459. Report. Climate Change; TNS Opinion \& Social: Brussels, Belgium, 2017.

69. Ministry of Environment. Report on Assessment of the Flood Risks; Ministry of Environment: Tallinn, Estonia, 2011.

70. Ministry of Environment. Climate Change Adaption Development Plan Until 2030; Ministry of Environment: Tallinn, Estonia, 2017.

71. Uustal, T. Development Plan for Adapting to the Climate Change in 2030; Proposal; Estonian Environmental Research Centre: Tallinn, Estonia, 2016.

72. Bulkeley, H.; Jordan, A. Transnational environmental governance: New findings and emerging research agendas. Environ. Plan. C Gov. Policy 2012, 30, 556-570. [CrossRef]

73. Brouwer, S.; Rayner, T.; Huitema, D. Mainstreaming climate policy: The case of climate adaptation and the implementation of eu water policy. Environ. Plan. C Gov. Policy 2013, 31, 134-153. [CrossRef]

74. Bouwer, L.M.; Aerts, J.C. Financing climate change adaptation. Disasters 2006, 30, 49-63. [CrossRef] [PubMed]

75. Andrew, J.; Andrea, L. Environmental policy integration: A state of the art review. Environ.Policy Gov. 2010, 20, 147-158.

76. Peters, B.G. Pursuing Horizontal Management: The Politics of Public Sector Coordination; University Press of Kansas: Laurence, KS, USA, 2015.

77. Pidgeon, N.; Kasperson, R.E.; Slovic, P. The Social Amplification of Risk; Cambridge University Press: Cambridge, UK, 2003.

78. Dietz, T.; Stern, P.C. Public Participation in Environmental Assessment and Decision Making; National Academies Press: Washington, DC, USA, 2008.

79. Shwom, R.; Bidwell, D.; Dan, A.; Dietz, T. Understanding u.S. Public support for domestic climate change policies. Glob. Environ. Chang. 2010, 20, 472-482. [CrossRef]

80. Shum, R.Y. Effects of economic recession and local weather on climate change attitudes. Clim. Policy 2012, 12, 38-49. [CrossRef]

81. Scruggs, L.; Benegal, S. Declining public concern about climate change: Can we blame the great recession? Glob. Environ. Chang. 2012, 22, 505-515. [CrossRef]

82. Milfont, T.L. The interplay between knowledge, perceived efficacy, and concern about global warming and climate change: A one-year longitudinal study. Risk Anal. Off. Publ. Soc. Risk Anal. 2012, 32, 1003-1020. [CrossRef] [PubMed] 
83. Kellstedt, P.M.; Zahran, S.; Vedlitz, A. Personal efficacy, the information environment, and attitudes toward global warming and climate change in the united states. Risk Anal. Off. Publ. Soc. Risk Anal. 2008, 28, 113-126. [CrossRef] [PubMed]

84. Demski, C.; Capstick, S.; Pidgeon, N.; Sposato, R.G.; Spence, A. Experience of extreme weather affects climate change mitigation and adaptation responses. Clim. Chang. 2017, 140, 149-164. [CrossRef]

85. Reser, J.P.; Bradley, G.L.; Ellul, M.C. Encountering climate change: 'Seeing' is more than 'believing'. Wiley Interdiscip. Rev. Clim. Chang. 2014, 5, 521-537. [CrossRef]

86. McDonald, R.I.; Chai, H.Y.; Newell, B.R. Personal experience and the 'psychological distance' of climate change: An integrative review. J. Environ. Psychol. 2015, 44, 109-118. [CrossRef]

87. Barriopedro, D.; Fischer, E.M.; Luterbacher, J.; Trigo, R.M.; Garcia-Herrera, R. The hot summer of 2010: Redrawing the temperature record map of europe. Science 2011, 332, 220-224. [CrossRef] [PubMed]

88. Anders, I.; Stagl, J.; Auer, I.; Pavlik, D. Climate change in central and eastern europe. In Managing Protected Areas in Central and Eastern Europe under Climate Change; Ranow, S., Neubert, M., Eds.; Springer: Dordrecht, The Netherlands, 2014; pp. 17-30.

89. Orru, H.; Ebi, K.L.; Forsberg, B. The interplay of climate change and air pollution on health. Curr. Environ. Health Rep. 2017, 4, 504-513. [CrossRef] [PubMed]

90. Macias, T. Environmental risk perception among race and ethnic groups in the united states. Ethnicities 2015, 16, 111-129. [CrossRef]

(C) 2018 by the authors. Licensee MDPI, Basel, Switzerland. This article is an open access article distributed under the terms and conditions of the Creative Commons Attribution (CC BY) license (http:/ / creativecommons.org/licenses/by/4.0/). 